\author{
Surapone Ptanawanit \\ Department of Social Work \\ Thammasat University, Thailand
}

\title{
The Organisational Engagement of Manual Labourers in a Transnational Corporation
}

\begin{abstract}
Huge competition in global markets and an insufficient supply of manual workers have together forced transnational corporations in Thailand to look for appropriate strategies to reduce labour costs and improve worker productivity. This study, therefore, examines factors influencing the work performance and organisational engagement of manual workers. For the research I randomly drew a sample of manual workers in a branch factory of a transnational food company to analyse their work performance, organisational engagement, and retention. The article finally suggests ways management can recruit manual labourers, improve their performance, and prolong their tenure with the organisation.
\end{abstract}

Keywords: organisational engagement, worker performance, worker retention, transnational workers.

\section{Introduction}

Under the highly competitive conditions in the world market and the shortage of domestic labour supplies, both local and transnational corporations in Thailand are now searching for appropriate human resource strategies for reducing production costs and increasing labour productivity. Employment of foreign labour has become a strategy commonly utilised by both small and large corporations. 
According to Huguet, Chamratrithirong, and Richter (2011), the number of foreign workers in Thailand is not less than 3 million and they are not decreasing in number. Although use of foreign labour does help reduce remuneration costs, it creates difficulties for human resource management in areas including administration, training, coaching, and the provision of welfare, particularly at the beginning of employment.

Many transnational corporations have moved their production bases to Laos, Cambodia, Indonesia, Vietnam, China, and other countries where cheaper labour is available. However, this requires a large amount of capital investment and is possible only for large corporations. Recently, Thailand's outward foreign direct investment has increased sharply, and is forecast to rise by 2020 to more than US\$ 18 billion (Ernst \& Young 2012). It is also accepted that the availability of cheaper labour is one of the reasons production has moved to other countries (Campos \& Kinoshita 2003).

In the domestic labour market, where the supply of manual labour has not met the increasing demand, wage and welfare increases are the main strategy for attracting new recruits. Despite being an effective alternative, increasing wages or welfare is an expensive choice, especially given that the new government policy on the daily minimum wage of 300 bahts (or approximately US\$10/day) has been in force for only a year. Competitive recruitments for manual workers based on an offensive compensation policy has created a wage war in which manufacturing firms have been attempting to win workers' hearts by offering higher financial incentives. Unfortunately, high wages and welfare seem to be a powerful incentive only in the short term as workers are always ready to accept better compensation from their organisations.

Many firms are, therefore, thinking of how to adapt a conventional means of enhancing employee engagement and productivity, which has long been limited to the white-collar workforce. These manufacturing firms do not want to bid for new workers against other firms. Instead, they intend to develop guidelines for finding prospective manual workers who can be productive and for retaining them. Not only should this development lessen labour costs but it should also improve workers' productivity, all of which can strengthen the firms' competitiveness in the world market. For large multinational corporations, the schemes for organisational engagement and manual workers' improved productivity will not benefit merely factories located in Thailand, but may become what is called "a global standard" their branch organisations in other countries can also apply.

This study aims to investigate factors affecting manual workers' performance and organisational engagement at a branch factory of a transnational company. The research findings are expected to lead to recommendations on how human 
resource management may improve workers' productivity and retention in this and other branch factories located in Thailand and other countries.

A number of studies have attempted to investigate what affects employee performance. Many emphasise the effect of demographic factors on productivity. Shaiful et al. (2009), for example, agreed in their study that gender did not have a significant effect on work performance. This contrasts with the findings of Benggtson et al. (1978), which showed that women performed better at work than men. Studies on the relationships between age and work performance also show contradictory findings. Some studies (Yearta 1995, Birren \& Schaie 2001) did not support the influence of age on work performance, while others did, including Smedley and Whitten (2006), Shultz and Adam (2007), and Kujala et al. (2005). Employees' educational background is another variable frequently considered in studies on work performance. Here too there has not been across the board agreement on its influence on work performance - some studies supported the effect of education (Ariss \& Timmins 1989, McBey \& Karakowsky 2001) while research conducted by Linz (2002) found that this variable had no influence.

In addition to demographic variables, management factors such as employee compensation, workplace environments, and human relations are often found to be related to work performance. Ryan and Deci (2000) believe that compensation is an extrinsic motivation which produces only a short-term effect on employee performance, while workplace environments, on the other hand, can better motivate employees to perform. Others (Mohr 1996, Huang, Robertson \& Chang 2004) pointed out a similar argument, their studies indicating a positive influence of physical environments on business results and employee well-being. Chandrasekar's work (2011) shed light on performance feedback, which included information exchange and conflict resolution between employees and supervisors. Some studies (Haynes 2008, Patterson et al. 1997) have emphasised the importance of behavioural components and the management of people to organisational performance.

With regard to employee retention and engagement, most studies tend to affirm that financial rewards can induce personnel to remain with an organisation. Padoa (2012), for example, stated in his study that $43.2 \%$ of the sample mentioned that a pay raise could lead them to stay on longer; however, approximately half chose non-financial benefits as a retention motivator. Some studies have argued that cash incentives produce only short-term effects. If the management expected long-term employee retention, non-financial motivators should be a better alternative to attracting employees to stay with an organisation. Among these studies is a survey done in the UK which found that only $10 \%$ of the employees who had left their organisation were dissatisfied with the wage they had received (Bevan 1997). Another study found that the most important factor in employee retention 
was to engage them with the employees' team and the organisational direction (Norman 2012). Higginbotham (1997) suggests that good and fair compensation is more important than high monetary payment, an argument that accords with the intrinsic motivation of an organisation's commitment by providing fair and equitable rewards proposed by Eby et al. (2000).

Like employee performance, many studies have tried to link organisational engagement with demographic characteristics such as gender, age, and education. In What Drives Employee Engagement and Why It Matters? gender, ethnicity, and work status were not found to be critical variables of engagement (Dale Carnegie Training 2012). This same study mentioned further that employees under 30 or over 50 years old were more engaged while the most highly educated were less engaged. Contradictory findings have been revealed by other researchers, who reported that females and older workers are more engaged (Avery, McKay \& Wilson 2007, James, Swanberg \& McKechnie 2007).

\section{Methods}

The study was designed as a sample survey. It collected data from the manual workers of a transnational food corporation's branch factory located in Nakornrachasima Province in northeastern Thailand. A few in-depth interviews with line supervisors were conducted as well, though these were not expected to answer research questions, only to provide some explanations to the survey results.

\section{Research Population}

The research population comprised approximately 2,700 manual workers who had been working in the factory for at least one year; their performance in 2013 was appraised.

\section{Sample}

Size. 2,700 was the sample size chosen based on the presumption about organisational engagement of manual workers. For the maximum sample size, the study presumed that half of the workers $(p=0.5)$ retained high organisational engagement, meaning the other half $(q=0.5)$ had a low level of organisational engagement.

The precision of the proportion estimate was set at 95\% $(d=0.05)$ and the significant level at 0.05 . Based on these presumptions, the study applied a simplified formula for estimating a population proportion (Yamane 1967) in determining sample size. This resulted in a sample size of 602 units. To increase the reliability of all the research findings, the sample size was enlarged to 700 units (or workers). 
Sampling technique. The human resource department prepared a population frame which listed all the names of manual workers. 700 names were randomly drawn from this frame, and it was from these workers that the data were collected.

\section{Research Instrument}

Apart from workers' demographic characteristics and employment status, another two sections dealing with organisational engagement and factors concerning worker retention were included.

Organisational engagement. This section comprised 16 five-scale rating questions which divided organisational engagement into four sub-sections: loyalty to the organisation, work adaptability, energy at work, and employment security.

Worker retention. This part asked the sample to choose only five factors (from each of the lists provided) that would make them happy at work, cause them to resign, cause their co-workers to resign, or convince them to stay with the organisation.

The instrument did not incorporate the issue of worker performance, though the human resource department prepared performance grades $(\mathrm{C}-, \mathrm{C}, \mathrm{B}, \mathrm{A}$, or $\mathrm{A}+$ ) of all the sampled workers appraised in the previous year for the study.

\section{Data Collection}

The data collection team from a private university in Bangkok was asked to become a third party to gather data from the workers. An individual interview according to the instrument inventories was the main method of data collection. However, I conducted interviews myself with a few line supervisors because this part of the data was used to provide additional clarity for the statistical analysis.

\section{Data Analysis}

The data were analysed using both descriptive and inferential statistics. Estimates of the population's proportions (or percentages) were the main descriptive statistics used to show the approximate overall findings. To avoid the limitations of the theoretical assumptions on population parameters which always occur in practice, appropriate non-parametric statistics were employed to test the statistical hypotheses. Pearson's chi-squared test and the Kruskal-Wallis test were the two inferential statistics used to generalise the findings to the whole population.

\section{Limitations}

The research objective and research population implied a few limitations of this study. First, the research is specifically concerned with manual workers, so 
the findings cannot apply to white-collar employees. Secondly, the population boundary covers only 2,700 workers in a branch factory of a multinational company. This means that generalisation of all the findings should not be made beyond this population boundary. Nevertheless, the human resource department of the multinational company that sponsored the research also intended to adapt some of the findings to improve the engagement and performance of workers in its other branch factories.

\section{Results}

$74 \%$ of the manual workers who responded to the questionnaires were females. The age of those who responded was approximately between 28 and 47 years. Approximately $67.9 \%$ of the workers were local residents while $32.1 \%$ of them had moved from other provinces.

\section{Worker Performance}

Most of the manual workers scored well on their performance assessments, with $84 \%$ receiving an $\mathrm{A}+$ or an $\mathrm{A}$. Only $16 \%$ were given a grade of $\mathrm{B}$ or below.

Two factors that influence high performance are employment tenure and education. Table 1 clearly shows that the workers with more than six years of employment are much more productive than those who have been working for not more than six years.

Table 1. Relationship between Employment Tenure and Work Performance

\begin{tabular}{|l|c|c|c|}
\hline \multirow{2}{*}{ Length of Employment } & \multicolumn{2}{|c|}{ Work performance (frequencies and percentage) } & \multirow{2}{*}{ Total } \\
\cline { 2 - 3 } & $\mathrm{A}$ and A+ & C- to B & \\
\hline 6 years and lower & 279 & 111 & 390 \\
& $(71.5 \%)$ & $(28.5 \%)$ & $(100.0 \%)$ \\
\hline More than 6 years & 309 & 1 & 310 \\
& $(99.7 \%)$ & $(0.3 \%)$ & $(100.0 \%)$ \\
\hline
\end{tabular}

Note: $p$ value from the Pearson's chi-squared test $=0.0000$.

Source: the author's own study.

As Ariss and Timmins (1989) and McBey and Karakowsky (2001) previously argued, this study also found that education is another factor that affects high performance. According to Table 2, the workers with a senior high school or technical education background are more efficient than those with primary education and particularly than those with a junior high school education. 
Table 2. Relationship between Level of Education and Work Performance

\begin{tabular}{|l|c|c|c|}
\hline \multirow{2}{*}{ Educational level } & \multicolumn{2}{|c|}{ Work performance (frequencies and percentage) } & \multirow{2}{*}{ Total } \\
\cline { 2 - 3 } & $\mathrm{A}$ and A+ & C- to B & \\
\hline Primary & 376 & 65 & 441 \\
& $(83.3 \%)$ & $(6.7 \%)$ & $(100.0 \%)$ \\
\hline Junior high school & 118 & 39 & 157 \\
& $(75.2 \%)$ & $(24.8 \%)$ & $(100.0 \%)$ \\
\hline $\begin{array}{l}\text { Senior high school } \\
\text { or technical education }\end{array}$ & 94 & 8 & 102 \\
\end{tabular}

Note: $p$ value from the Pearson's chi-squared test $=0.0000$.

Source: the author's own study.

A few points are worth discussing. First, high performance is undeniably influenced by work experience and length of employment. Better education is also a significant cause of high performance. Table 2 does not imply that workers with primary education are more productive than those with a junior high-school background, but it actually confirms the effect of work experience mentioned in the previous topic as more than $70 \%$ of the workers with a primary education are mostly the persons with more than 6 years of employment.

The second point concerns manual work in this factory and perhaps across the entire food processing industry: since the data showed that the workers who had a longer employment period were mostly older individuals, we may conclude that workers can maintain high performance until they reach at least 50 years of age. The findings from the in-depth interviews confirm the statistical analysis - all of the supervisors interviewed agreed that the performance of the older workers was still competitive with that of the younger ones. The findings from both the quantitative and qualitative analyses, therefore, support the positive effects of age found by Smedley and Whitten (2006), Shultz and Adam (2007), and Kujala et al. (2005). Qualities including punctuality, obedience or being less problematic, and patience helped the older workers receive better performance grades.

Lastly, the findings indirectly indicate that local workers are more efficient than those who migrated from other provinces. This conclusion is based on the fact that the workers with a primary education, or with longer tenure, or who are more senior, were mostly locals who had been employed by the factory since it opened 9 years ago.

\section{Organizational Engagement}

In all, the manual workers had an average score of $87.6 \%$ on organisational engagement. They scored $90.6 \%$ on worker loyalty and $87.6 \%$ on employment 
security. The average scores for the other two parts of "energy at work" and "work adaptability" were $84.1 \%$ and $80.6 \%$, respectively.

Two important factors tied to organisational engagement are educational background and length of employment at the organisation. As far as the latter factor is concerned, the older workers received a significantly higher average for loyalty than their younger counterparts did. As for educational background, the workers with lower education scored significantly higher in all aspects of organisational engagement than those with a better education (Table 3).

Table 3. Organisational Engagement Scores by Level of Education

\begin{tabular}{|l|c|c|c|c|}
\hline \multirow{2}{*}{\multicolumn{1}{|c|}{ Level of education }} & \multicolumn{4}{|c|}{ Aspect of organizational engagement (average score) } \\
\cline { 2 - 5 } & loyalty & $\begin{array}{c}\text { work } \\
\text { adaptability }\end{array}$ & $\begin{array}{c}\text { energy } \\
\text { at work }\end{array}$ & $\begin{array}{c}\text { employment } \\
\text { security }\end{array}$ \\
\hline Primary education & 18.4 & 24.6 & 12.8 & 17.8 \\
\hline Junior high school & 17.7 & 23.9 & 12.3 & 17.3 \\
\hline $\begin{array}{l}\text { Senior high school or technical } \\
\text { education }\end{array}$ & 17.6 & 23.4 & 12.3 & 16.8 \\
\hline $\begin{array}{l}p \text { value from the Kruskal-Wallis } \\
\text { test }\end{array}$ & 0.000 & 0.004 & 0.003 & 0.000 \\
\hline
\end{tabular}

Source: the author's own study.

Agreement between the findings of this and the previous categories suggests a few conclusions. First, length of employment, organizational engagement, and worker performance are interrelated. A longer period of employment leads to organisational engagement, which ultimately results in better performance. Management may choose to employ applicants with better education in manual work positions and expect high performance from them. However, the price they pay for this alternative will be less loyalty to the organisation. Therefore, to employ applicants with a primary education is not a bad choice because management is able to make them highly engaged in every respect and eventually to be productive workers, although they may take a longer time to develop than those with a better education do.

\section{Worker Retention}

The critical period for worker retention was the workers' first five years of employment, particularly in their initial year during which more than $50 \%$ of new recruits decided to leave the organisation. Turnover rates clearly dropped after the first five years of employment and tended to be stable afterward. 
Factors affecting length of employment. A few factors were found to have some relation with length of employment. In terms of gender, the study found that the female workers had approximately 1.5 years of employment longer than their male counterparts. This difference was statistically significant $(p=0.000)$ and is considerable for a factory running for less than 10 years.

The local workers had an average length of employment of 5.3 years, which was significantly longer $(p=0.000)$ than the 4.5 years of those who migrated from the neighbouring province of Buriram and particularly the 3.7 years of migrant workers from other provincial locations.

Educational background also had some effect upon length of employment. The workers with a primary education were employed, on average, for 5.5 years, which was significantly longer $(p=0.000)$ than the 4.3 years and 4.0 years of those with a junior high school education and with a senior high school/technical education, respectively.

The finding concerning length of employment affirms the greater loyalty to the organisation of the manual workers who are local residents and of those who have a lower educational background. In terms of gender, the present recruitment practice, which tends to employ more females than males, seems to be appropriate as the study showed that the female workers stayed with the organisation longer than their male counterparts did.

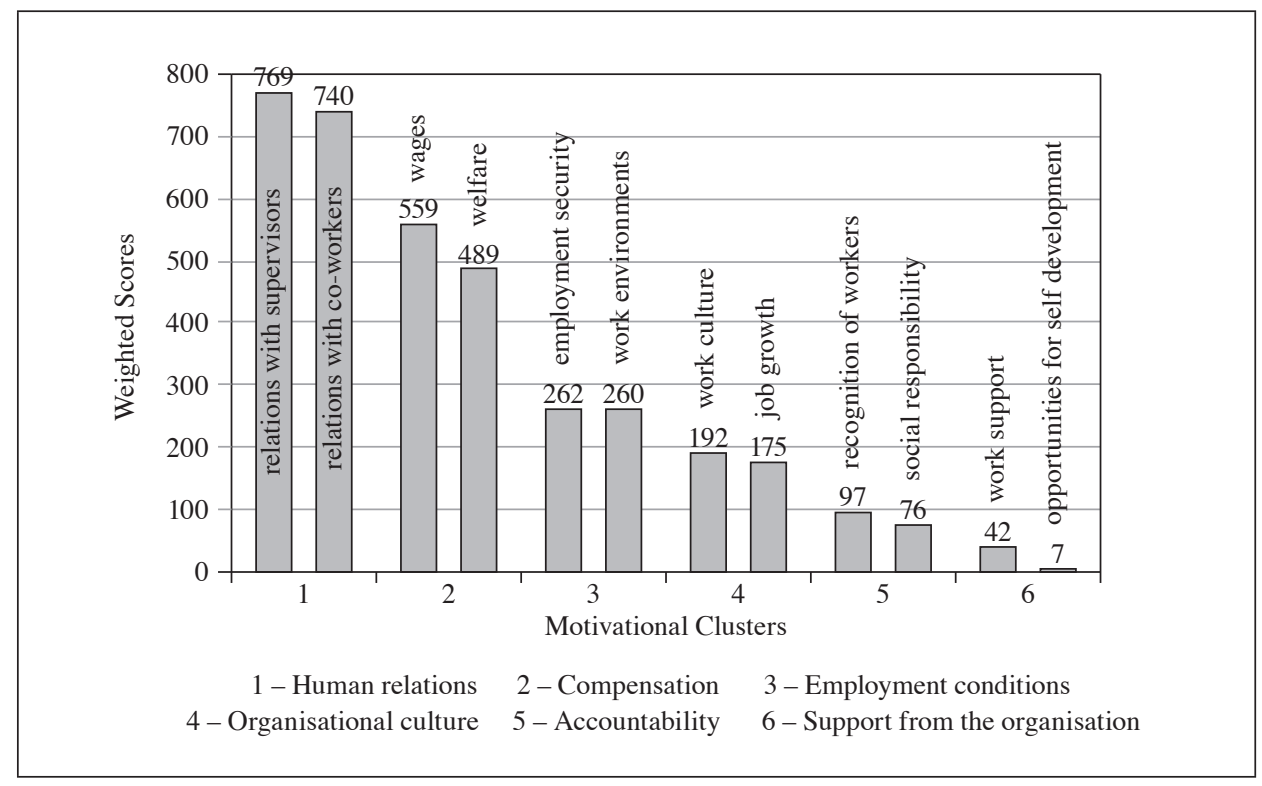

Fig. 1. Motivational Factors in Worker Retention

Source: the author's own study. 
Motivational factors. The manual workers were asked to choose the five most important factors from the lists that would compel them or their colleagues to stay with the organisation, cause them or their colleagues to resign, and make them happy at work. The scores determined by the ranking and the percentages of the respondents indicated six clusters of motivations that could induce worker retention. Chart 1 shows that, for the manual workers whose economic status was at a decent level, the work compensation cluster ranks behind human relations, which includes relations with immediate supervisors and co-workers. This would seem to deny the strong influence of a financial reward stated by Padoa (2012), but confirms the importance of an intrinsic motivator found by Bevan (1997) and Norman (2012). Another important cluster is employment conditions, which include employment security and work environments. However, the scores of its components are still far behind those in the first two clusters.

The manual workers seem not to value intangible motivators. As Fig. 1 illustrates, the scores of the components in the other three clusters are rather low - including even opportunities for self development, which came in with a score of as low as 7.1.

\section{Conclusion and Recommendations}

Empirical findings based on the data collected from the manual workers at the transnational organisation I have considered lead to some conclusions on worker performance and organisational engagement. First, a better educational background is fundamental to employees working at a high performance level. Another cause of high performance is work experience reflected by length of employment. This helps explain why a significantly higher proportion of older workers receive A and A+ performance grades than younger ones do.

The analysis showed the advantages of using local workers, who had a lower educational background but nonetheless high performance grades for all aspects of organisational engagement. These local labourers have worked with the organisation for a longer time than workers who migrated from other provinces. This brings us to another conclusion - that local people should be more preferable than migrant workers. Finally, female workers did not show significantly higher organisational engagement scores, but their tenure was 1.5 years longer than their male counterparts.

In this transnational establishment where payment of wages and welfare provision are better than the minimum required by law, the decision to stay with or leave the organisation depended greatly on whether employees had good relations or conflicts with supervisors and co-workers. The workers' demands 
for better wages and welfare proved to be the second priority after the human relations cluster. Another two influential factors in keeping the workers with the organisation were employment security and work environments. Abstract forms of motivators such as the organisation's accountability, its support, and opportunities for self-development were not influential enough to extend a manual worker's desire to stay.

The research findings suggest some guidelines that may be followed by managers recruiting new manual workers, improving the performance of new workers and boosting retention rates. These guidelines could probably also be applied by other multinational food manufacturing firms.

In the search for highly engaged and efficient workers, management should primarily recruit new workers from local applicants. Females may well be more preferable; however, this conclusion must not lead to discrimination against male applicants. New recruits with better education, particularly in an appropriate field of technical education, can develop high performance within a shorter period of time than individuals with a lower education. However, management may have to spend more money on payroll and cannot expect loyalty from these better-educated workers. It may therefore turn its attention to applicants with a primary education and some work experience because the research findings suggest that this group of workers is capable enough to obtain an A or A+ performance level, though they may require more time to develop their skills. Another advantage of hiring manual workers with a lower level of education is that they are more engaged than those with better education. This translates into reduced worker turnover and recruitment costs.

Regarding the employment of applicants with a lower educational background who have some work experience, management might avoid recruiting new graduates, but should give priority to more mature applicants. This will help save social security costs and the management can still expect high performance from these more mature workers until their retirement.

Although management does not need to offer very high compensation in promoting worker retention, it must be competitive and comply with labour law. Enhancing workers' good relations with immediate supervisors and co-workers is the most important motivator for retaining manual workers. Employment security and a decent work environment must also be provided to improve worker retention. For the manual workers in this setting, intangible and internalised rewards such as self-development, recognition from the organisation, and organisational accountability are too abstract for the workers to realise their value. 


\section{Bibliography}

Ariss S. S., Timmins S. A. (1989), Employee Education and Job Performance: Does Education Matter?, "Journal of Public Personnel Management”, 18(2): 100-112.

Avery D. R., McKay P. F., Wilson D. C. (2007), Engaging the Aging Workforce: The Relationship between Perceived Age Similarity, Satisfaction with Coworkers, and Employee Engagement, "Journal of Applied Psychology", 92(6): 1542-1556, http:// dx.doi.org/10.1037/0021-9010.92.6.1542.

Benggtson C., Vedin J. A., Grimby G., Tibblin G. (1978), Maximal Work Performance Test in Middle-aged Women: Results from a Population Study, "Scandinavian Journal of Clinical and Laboratory Investigation", 38(2): 181-188.

Bevan S. (1997), Quit Stalling (Retention), "People Management", 3(23): 32-35.

Birren J. E., Schaie K. W. (2001), Handbook of the Psychology of Aging, Gulf Professional Publisher, London.

Campos N. F., Kinoshita Y. (2003), Why Does FDI Go Where It Goes? New Evidence from the Transition Economies, https://www.imf.org/external/pubs/ft/wp/2003/ wp03228.pdf, accessed: January 2, 2014.

Chandrasekar K. (2011), Workplace Environment and Its Impact on Organizational Performance in Public Sector Organizations, "International Journal of Enterprise Computing and Business Systems", 1(1), www.ijecbs.com/January2011/N4Jan2011. pdf, accessed: December 20, 2013.

Dale Carnegie Training (2012), What Drives Employee Engagement and Why It Matters, www.dalecarnegie.com/assets/1/7/driveengagement_101612_wp.pdf, accessed: November 29, 2013.

Eby L. T., Adams D. M., Russel J. E. A., Gaby S. H. (2000), Perceptions of Organisational Readiness for Change. Factors Related to Employees' Reaction to the Implementation of Team-based Selling, "Human Relations", 53(3): 419-442, http://dx.doi.org/ 10.1177/0018726700533006.

Ernst \& Young (2012), Beyond Asia: Strategies to Support the Quest for Growth/Thailand Highlights, www.bot.or.th/Thai/FinancialMarkets/ThaiDirectInvertment/Document/ ThailandHighlights_ErnstAndYoung.pfd, accessed: January 2, 2014.

Haynes B. P. (2008), An Evaluation of the Impact of the Office Environment on Productivity, "Journal of Facilities", 26(516): 178-190.

Higginbotham J. S. (1997), The Satisfaction Equation, "Research \& Development", 39(10): 1-9.

Huang Y. H., Robertson M. M., Chang K. I. (2004), The Role of Environmental Control on Environmental Sastisfaction, Communication, and Psychological Stress: Effect of Office Ergonomics Training, "Environment and Behavior", 36(5): 617-638, http://dx.doi.org/10.1177/0013916503262543.

Huguet J. W., Chamratrithirong A., Richter K. (2011), Thailand Migration Profile (in:) J. W. Huguet, A. Chamratrithirong (eds), Thailand Migration Report 2011, International Organization for Migration, Bangkok.

James J. B., Swanberg J. E., McKechnie S. P. (2007), Responsive Workforces for Older Workers: Job Quality, Flexibility and Employee Engagement, The Center for Aging and Work/Workplace Flexibility at Boston College, Chestnut Hill, MA.

Kujala V., Remes J., Ek E., Tammelin T., Laitinen J. (2005), Classification of Work Ability Index among Young Employees, "Journal of Occupational Medicine”, 55(5): 399-401. 
Linz S. (2002), Job Satisfaction among Russian Workers, http://ssm.com/abstract313641orDQI:10.2139/ssm.313641, accessed: December 15, 2013.

McBey K., Karakowsky L. (2001), Examining Sources of Influence on Employee Turnover in the Part-time Context, "Journal of Career Development International", 21(3): 136-144.

Mohr R. (1996), Office Space Is a Revenue Enhancer, Not an Expense, "National Real Estate Investor", 38(7): 46-47.

Norman M. (2012), 6 Ways to Retain Remote Workers - and Make Them Feel Part of the Team, http://www.tlnt.com/2012/03/20/6-ways-to-retain-remote-workers-and-makethem-feel-part-of-the-team, accessed: December 1, 2013.

Padoa C. (2012), The Other 3 R's: Recognition, Remuneration, and Retention, http:// bx.businessweek.com/employeeretention/view?url=http\%3A\%2F\%2Fwww.Executionandstrategy.com $\% 2 \mathrm{~F} 2012 \% 2 \mathrm{~F} 06 \% 2$ Fother-3-rs-recognition-remuneration-and.html, accessed: December 5, 2013.

Patterson M. G., West M. A., Lawthorn R., Nickell S. (1997), Impact of People Management Practices on Business Performance, Issues in People Management No. 22, Institute of Personnel and Development, London.

Ryan R. M., Deci E. L. (2000), Self-determination Theory and the Facilitation of Intrinsic Motivation, Social Development, and Well-being, "American Psychologist", 55(1): 68-78, http://dx.doi.org/10.1037/0003-066x.55.1.68.

Shaiful A. K., Kamaruzaman J., Hassan A., Mohamad I., Kamsol M. K., Norhasimah A. R. (2009), Gender as Moderator of the Relationship between OCB and Turnover Intention, "Journal of Asian Social Science", 5(6): 108-117.

Shult K. S., Adam G. A. (2007), Aging and Work in the 21st Century, Routledge Publisher, New Jersey.

Smedley K., Whitten H. (2006), Age Matters: Employing, Motivation, and Managing Older Employees, Gower Publishing, Hampshire, UK.

Yamane T. (1967), Elementary Sampling Theory, Prentice-Hall, Englewood Cliffs, NJ.

Yearta S. K. (1995), Does Age Matter?, "Journal of Management Development", 14(7): 28-35.

\section{Zaangażowanie organizacyjne pracowników operacyjnych w korporacji transnarodowej}

Silna konkurencja na rynkach globalnych oraz niewystarczająca podaż pracowników operacyjnych skłaniają korporacje transnarodowe w Tajlandii do poszukiwania odpowiednich strategii zmniejszania kosztów pracy i podnoszenia produktywności pracy. W opracowaniu skoncentrowano się na zbadaniu czynników wpływających na efekty pracy i zaangażowanie pracowników operacyjnych. Badania empiryczne przeprowadzone zostały na próbie pracowników w fabryce należącej do korporacji transnarodowej działającej w branży spożywczej. Ich zakres obejmował analizę efektywności pracy, zaangażowania organizacyjnego oraz retencji pracowników. Na tej podstawie sformułowano wnioski dotyczące rekrutacji, podnoszenia efektywności pracy i retencji pracowników.

Słowa kluczowe: zaangażowanie organizacyjne, efekty pracowników, retencja pracowników, pracownicy transnarodowi. 